\title{
ETIKA JURNALISTIK DALAM PERSPEKTIF HUKUM ISLAM
}

\author{
Zainal Abidin Muhja \\ Fakultas Hukum, Universitas Borneo Tarakan \\ Tarakan, Kalimantan Utara, Indonesia \\ zainalabidinmuhja@gmail.com \\ Liza Shahnaz \\ Fakultas Hukum, Universitas Borneo Tarakan \\ Tarakan, Kalimantan Utara, Indonesia \\ lizashahnaz@gmail.com
}

\begin{abstract}
This article highlights the importance of journalistic ethics concerning disseminating information to the public, especially on social media, so that community unity and integrity are maintained and are not easily provoked by false issues. This research is legal research using a normative approach and Islamic literature approach. This research found that a Muslim journalist must put forward several principles: tabayyun, positive thinking, and intention not to spread fake news.
\end{abstract}

Keyword (s): Ethics, Journalistics, Islamic law.

\section{PENDAHULUAN}

Komunikasi masyarakat sekarang ini lebih banyak dilakukan melalui media sosial. Sebagian masyarakat lebih banyak waktunya berinteraksi dengan kawankawannya di media sosial dibandingkan dengan berinteraksi di dunia nyata. Hal ini terjadi karena perkembangan internet dan bertambah jumlah penggunanya. Dahulu jika ingin berkumpul dengan ratusan bahkan ribuan orang, maka hal itu memerlukan kepada tempat yang luas dan waktu yang lama. Pada zaman sekarang, orang dengan jumlah yang banyak bisa berkumpul di salah satu aplikasi komunikasi di media sosial tanpa harus menggunakan tempat yang luas dan waktu yang lama. Kemajuan teknologi ini semuanya diinovasi untuk semakin memudahkan urusan manusia. Belanja tidak perlu pergi ke pasar, cukup dengan ujung jari apa yang diinginkan bisa diantarkan sampai ke depan pintu rumah.

Kemajuan teknologi yang memudahkan manusia untuk berurusan dan berkomunikasi memiliki dampak positif maupun dampak negatif. Sebagian pengguna ketika menggunakan media sosial, seakan-akan memiliki dua karakter kepribadian. Di dunia nyata, menampilkan pribadi yang ramah. Namun di dunia maya, tampil sebagai pribadi yang berbeda. Misalnya sering mengungkapkan kemarahan dengan 
menggunakan kata-kata yang tidak terpuji. Pada lain kesempatan, ada yang sebenarnya bukan orang yang suka bersosialisasi tetapi di dunia maya, menampakkan hal sebaliknya. Sebagian orang pada media sosial juga memiliki dua karakter; karakter yang baik di media sosial dan karakter yang buruk di dunia nyata atau sebaliknya.

Budaya timur serta pola pikir sebagian besar masyarakat juga ikut berubah akibat dampak kemajuan teknologi. Media sosial menjadi tempat untuk saling menghina, mencemarkan nama baik, membagikan tautan porno, dan penipuan di dunia maya.12 Ponsel yang pintar harus didukung dengan kedewasaan orang yang menggunakannya. Jangan sampai timbul istilah "Smartphone, Stupid Man". Istilah ini menggambarkan banyaknya orang yang mampu membeli handphone yang mahal, tetapi tidak mampu mempergunakan untuk perihal yang mendatangkan kemanfaatan baik untuk dirinya maupun untuk masyarakat. ${ }^{13}$ Maka, tulisan ini akan membahas mengenai etika jurnalistik, sehingga para pengguna media sosial lebih bijak dalam menyebarkan informasi di media sosial.

\section{Rumusan Masalah}

Dengan latar belakang di atas, maka rumusan masalah dalam tulisan ini difokuskan pada etika jurnalistik dalam perspektif hukum islam.

\section{Metode Penelitian}

Penelitian ini merupakan penelitian normatif dengan menggunakan Al-Qur'an dan AsSunnah beserta tafsirnya sebagai data primer. Pendekatan literatur islam juga digunakan untuk menjelaskan tentang konsep berita baik dan konsep lain yang berkaitan dengan penelitian ini.

\section{Pembahasan}

\section{Pandangan Islam Tentang Jurnalistik}

Etika secara bahasa adalah sopan santun, tata krama, budi pekerti, tata susila, moral, akhlak, pengetahuan tentang moral. Etika dalam artian maknawi adalah suatu nilai batasan terhadap tindakan manusia dalam pergaulan. Etika dapat disebut dengan istilah ethic berasal dari bahasa latin yang artinya kesusilaan atau moral, bahasa Yunani ethos yang artinya kebiasaan-kebiasaan yang baik, dalam bahasa Inggris ethics yang

\footnotetext{
12 P. Agung, F. Marisa, “Analisis Statistik Pada Dampak Negatif Dari Sosial Media Terhadap Perilaku Manusia”, Journal of Information Technology and Computer Science, Vol. 4, No. 1, Januari 2019. h. 2.

${ }^{13}$ Afandi, Irfan. Hoax dalam Sejarah Islam Awal (Kajian Kritis Tentang QS. An-Nur: 11-20). Ar-Risalah, Vol. XVI No. 1 April 2018. h. 145.
} 
artinya ukuran-ukuran prilaku atau tindakan-tindakan yang tepat atau moral. ${ }^{14}$ Jurnalistik bermakna sesuatu yang berkaitan dengan kewartawanan dan persuratkabaran. ${ }^{15}$ Menurut Onong Uchjana Effendy jurnalistik adalah teknik mengola berita sejak dari mendapatkan bahan sampai kepada menyebarluaskannya kepada khalayak. ${ }^{16}$ Secara umum, etika jurnalistik adalah ikatan moral dan penghormatan orang yang menyebarkan berita terhadap norma-norma moral yang mulia, yang harus dijadikan dasar pertimbangan dalam setiap penyebaran berita.

Sebagai seorang muslim yang menjalankan aturan-aturan Islam, seyogyanya seorang muslim memperhatikan aturan-aturan Islam dalam menyebarkan informasi atau berita baik di dunia nyata maupun di dunia maya. Hal ini dikarenakan apa yang ditulis di media sosial pada hakikatnya adalah apa yang diucapkan dari lisan. Tulisan adalah bagian dari ucapan seseorang. Sehingga apa yang ditulis harus dipikirkan terlebih dahulu, apakah akan memberikan manfaat kepada dirinya atau jutsru akan membahayakan dirinya dan orang banyak. Setiap ucapan yang keluar akan dicatat oleh malaikat. Allah Subhanahu Wa Ta'ala berfirman:

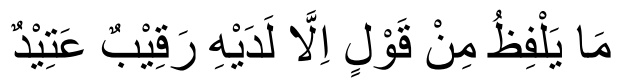

Maknanya: "Tidak ada suatu kata yang diucapkannya melainkan ada di sisinya malaikat pengawas yang selalu siap (mencatat)."(Q.S. Qaf: 18).

Ayat di atas mengingatkan manusia untuk berhati-hati dalam setiap ucapan yang dikeluarkan. Karena setiap ucapan yang dikeluarkan pasti dicatat oleh malaikat. Jika ucapan tersebut baik, maka beruntunglah orang tersebut. Jika ucapan yang keluar adalah sesuatu yang bertentangan dengan agama, maka binasalah orang tersebut akibat ucapannya. Begitu juga dalam hal tulisan atau informasi yang akan diberikan. Jika memberikan manfaat, maka yang menulis atau menyebarkan informasi tersebut mendapatkan kebaikan juga dari apa yang disebarkan. Sebaliknya jika yang disebarkan adalah sesuatu yang memudharatkan dirinya atau orang lain, maka yang menyebarkanpun akan mendapatkan bagian dari mudharat tersebut.

Islam sangat menganjurkan untuk menyebarkan kebaikan termasuk di dalamnya informasi atau berita yang baik. Terlebih lagi jika yang disebarkan tersebut adalah

\footnotetext{
${ }^{14}$ Fathullah. 2007. Komunikasi Etika \& Hubungan Antar Manusia. Semarang: Duta Nusindo. H. 57.

${ }^{15} \mathrm{KBBI}$, https://kbbi.web.id/jurnalistik, akses 15 Juli 2020.

${ }^{16}$ Tahrun, dkk. 2019. Keterampilan Pers Dan Jurnalistik Berwawasan Jender. Yogyakarta: Deepublish. H. 53
} 
informasi atau berita kebaikan agar dapat dilakukan dan diikuti oleh orang lain. Berita seorang yang walaupun pendapatannya berkecukupan, ia tetap bersedekah membantu orang lain. Berita seseorang walaupun umur sudah tua, ia tetap membaca al Quran dan dapat mengkhatamkannya dalam beberapa hari. Berita-berita kebaikan seperti ini jika disebarkan dengan niat untuk mengajarkan kebaikan pada orang lain dan diikuti oleh orang lain, maka hal ini sangat dianjurkan di dalam Islam. Dalam satu hadits yang shahih Rasulullah Shallallaahu 'alaihi wa sallam menjelaskan bahwa orang yang mengajarkan kebaikan maka para malaikat, penduduk bumi, semut di dalam lubang, dan ikan yang ada di lautan ikut mendoakan ampunan bagi orang yang menyebarkan kebaikan ${ }^{17}$.

Islam juga membenarkan untuk menyebarkan berita yang baik sebagai bukti rasa syukur kepada Allah Subhanahu Wa Ta'ala. Jika seseorang mendapatkan nikmat kebaikan, maka dianjurkan untuk dinyatakan. Hal ini sesuai dengan Firman Allah Subhanahu Wa Ta'ala:

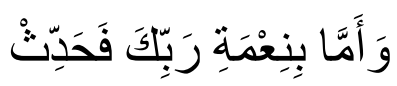

Maknanya: "Dan terhadap nikmat Tuhanmu, maka hendaklah kamu siarkan"(Q.S. adhDhuha: 11)

Ayat ini menganjurkan kepada manusia untuk menyebarkan nikmat Allah yang didapatkan kepada orang yang dipercayai. Disebutkan orang yang dipercayai, agar informasi yang diberikan tidak ditanggapi dengan sesuatu yang negatif atau disalahgunakan oleh orang yang menerima informasi kebaikan tersebut.

Dalam menyampaikan berita atau informasi kepada orang lain baik secara langsung maupun di media sosial, ada beberapa hal yang harus diperhatikan. Di antaranya adalah

1. Tidak menyebarkan berita bohong (hoax)

Berbohong adalah dosa lisan yang dilarang di dalam Islam. Berbohong adalah menyampaikan berita tidak sesuai dengan fakta yang ada secara sengaja. ${ }^{18}$ Berbohong tidak dibenarkan baik dalam keadaan serius maupun bercanda. Rasulullah Shallallaahu 'alaihi wa sallam menjelaskan dalam sebuah hadits bahwasanya tidak dibenarkan

\footnotetext{
17 Ibnu Hibban. 1952. Shahih Ibnu Hibban. Cairo: Dar al Ma'arif. No. 88.

${ }^{18}$ Al Harari, Abdullah. 'Umdah ar-Raghib. Cet. II. Beirut: Dar al Masyari. 2009. H. 369.
} 
berbohong baik dalam keadaan serius maupun bercanda ${ }^{19}$. Termasuk dalam hal ini adalah berbohong dalam menyampaikan informasi yang tidak benar, walaupun hal tersebut hanya melalui media sosial. Baik informasi yang bohong tersebut disampaikan dalam bentuk video maupun tulisan. Hal ini dikarenakan tulisan adalah salah satu dari lisan.

Penyebaran berita bohong di masyarakat terjadi akibat mudahnya untuk mendapatkan berita bohong tersebut, baik dari aplikasi percakapan (chatting) maupun media sosial. Hal ini menunjukkan bahwa hoax sudah masuk ke dalam aspek pribadi dan tersebar dari jejaringan pertemanan. Banyaknya beredar berita bohong dapat mengganggu keamanan masyarakat dan memicu pengrusakan seperti yang terjadi pada pembakaran polsek Ciracas pada Sabtu 28 Agustus 2020.20 Merebaknya peredaran berita bohong memberikan beberapa dampak negatif terhadap masyarakat. Di antaranya adalah merugikan masyarakat karena hoax adalah kebohongan besar, memecah belah persatuan dan kesatuan bangsa, dan menjadi provokator yang merugikan masyarakat. Oleh karena itu, masyarakat harus semakin bijak dalam menanggapi berita-berita bohong dan tidak mudah terpancing. ${ }^{21}$

Sebenarnya penyebaran berita bohong seperti zaman sekarang ini sudah terjadi sejak zaman Rasulullah Shallallaaahu 'alaihi wa sallam. Hal ini bisa dilihat tentang berita bohong ke atas istri baginda Rasulullah Shallallaahu 'alaihi wa sallam atas tuduhan zina kepada beliau semoga Allah meridhainya. Peristiwa ini juga menjadi asbab nuzul ayat 11 dari surah an-Nur. Ketika beliau pulang dari Madinah bersama pasukan kaum muslimin. Dalam sebuah perjalanan, Sayyidah 'Aisyah kehilangan kalungnya. Ketika beliau mencari kalungnya, pasukan kaum Muslimin melanjutkan perjalanan mereka dan mengira beliau sudah bersama mereka. Pada saat itu Aisyah menyadari bahwa ia telah ketinggalan dan ia pun menjadi kebingungan sehinggat tertidur karena rasa kantuknya. Setelah beberapa waktu, Safwan bin al Mu'aththal as-Sulami ad-Dakhwani melihat istri Rasulullah Shallallahu 'alaihi wa sallam tersebut. Shafwan pun mengucapkan innaa lillaahi dan membawa Sayyidah Aisyah kepada pasukan kaum muslimin. Namun setelah terjadi peristiwa itu, beberapa orang mulai ramai membicarakan peristiwa tersebut dan

\footnotetext{
19 Ibnu Majah, Muhammad. Sunan Ibn Majah. Cairo: Dar Ihya al Kutub al 'Arabiyah H. 18

${ }^{20}$ https://www.liputan6.com/news/read/4343268/ternyata-ini-penyulut-pembakaran-polsek-ciracas, diakses 24 September 2020.

${ }^{21}$ Maulana, Luthfi. 2017. Kitab Suci Dan Hoax: Pandangan Alquran Dalam Menyikapi Berita Bohong.

Wawasan: Jurnal Ilmiah Agama dan Sosial Budaya. H. 213.
} 
menyebarkan hoax tentang Aisyah (semoga Allah meridhainya). Hingga selama sebulan Aisyah merasakan ada yang berbeda dari Nabi Shallallaahu 'alaihi wa sallam. Aisyah terus berdoa kepada Allah agar masalah yang sedang dihadapinya selesai, hingga Allah menurunkan ayat 11 dari surah an-Nur. Dalam ayat tersebut Allah menjelaskan kepada Rasulullah Shallallaahu 'alaihi wa sallam bahwa orang-orang yang membawa berita bohong tersebut adalah dari golongan umat Islam. Janganlah hal tersebut dianggap sebagai hal yang buruk bahkan ada kebaikan yang bisa diambil dari peristiwa tersebut. Setiap orang yang menyebarkan berita bohong tersebut akan mendapatkan balasan berupa adzab atas apa yang dilakukannya. Ayat ini merupakan kecaman besar terhadap orang-orang yang menuduh Aisyah tanpa bukti-bukti. Dari penjelasan ayat ini dapat dipahami bahwa potensi hoax sendiri sudah terjadi di zaman Rasulullah Shallallahu 'alaihi wa sallam.

Dalam pandangan Islam orang yang menyebarkan berita bohong diancam dengan adzab baik di dunia maupun di akhirat sebagaimana yang disebutkan dalam ayat 19 Surah an-Nur. Adzab yang pedih menanti bagi orang yang suka menyebarkan fahisyah; penyebutan hoax di dalam ayat 19 surah an-Nur ayat 19. Sebagian orang memahami bahwa dalam menyebarkan berita bohong terdapat keuntungan bagi satu pihak. Akan tetapi, ketahuilah bahwa bukan keuntungan yang didapatkan justru adzab yang menanti baik di dunia maupun di akhirat. Pada ayat berikutnya Allah menyebutkan bahwa Dia adalah Maha Penyantun dan Maha Penyayang. Hal ini menunjukkan orang-orang yang menjadi korban hoax selalu dalam lindungan Allah. Sebaliknya orang yang suka menyebarkan berita bohong akan selalu diintai dengan adzab Allah baik di dunia maupun di akhirat. Melainkan ia bertaubat kepada Allah dengan menyesal dan berjanji untuk tidak menyebarkan berita bohong lagi. Bahkan islam juga menganjurkan agar menjadi agen untuk menjadi penggerak gerakan anti hoax.

Dalam ajaran Islam dibenarkan berbohong dalam tiga perkara. Diriwayatkan dari Ummu Kaltsum binti 'Uqbah berkata: "Saya mendengar Rasulullah Shallallahu 'alaihi wa sallam bersabda yang maknanya: "Bukanlah pembohong orang yang memperbaiki hubungan antara manusia (yang bertengkar), sehingga dia menyampaikan (berita) kebaikan dan mengirimkan (berita) kebaikan". Saya tidak mendengarkan nabi memberikan pengecualian kepada yang dikatakan orang-orang 
tentang kebohongan kecuali pada tiga perkara: peperangan, memperbaiki hubungan, dan ucapan suami ke istri atau sebaliknya". ${ }^{22}$ Hadits ini dijelaskan tentang kebohongan yang dibenarkan, pertama, berbohong saat perang demi kemenangan pasukan kaum muslimin. Seperti mengatakan kami akan pergi ke tempat A. Akan tetapi pada hakikatnya mereka akan pergi ke tempat B. Kebohongan ini dilakukan untuk strategi perang dan tidak dikatakan pengecut, demi kemenangan pasukan kaum muslimin. Kedua, berbohong demi memperbaiki hubungan dua orang atau dua kelompok yang sedang bertikai. Seseorang datang kepada kelompok A mengatakan kebaikan dari kelompok lawan, dan sebaliknya ia pergi atau mengirimkan berita kepada kelompok lawan bahwa kelompok A mengatakan kebaikan tentang mereka. Pada akhirnya kedua kelompok saling berbaikan, walaupun pada hakikatnya apa yang disampaikan adalah kebohongan. Dalam hal ini, tidak dikatakan kebohongan karena untuk memperbaiki hubungan kedua pihak yang sedang bertikai. Ketiga, perkataan suami kepada istri atau sebaliknya. Jika terjadi sesuatu kepada salah satu pasangan yang mana jika diketahui oleh pasangan yang lain pasangannya akan merasa khawatir dan gelisah, maka dibenarkan untuk berbohong agar tidak menjadikan pasangan tersebut khawatir ke atas dirinya. Misalnya suami dipukul oleh orang yang menagih hutang yang dilakukan oleh suami demi membantu kehidupan keluarganya. Ketika pulang ke rumah istri bertanya mengenai penyebab luka di tubuhnya, suami mengatakan jatuh dari motor agar sang istri tidak khawatir dengan keadaan suami. Keadaan seperti ini dibenarkan dalam Islam, dan tidak dikatakan sebagai kebohongan yang diharamkan.

2. Tidak menyebarkan aib/kekurangan orang lain

Islam mengajarkan untuk tidak menyebarkan kekurangan atau aib orang lain. Bahkan yang dianjurkan di dalam Islam adalah ketika mendapatkan berita tentang kekurangan orang lain yang dilakukan adalah menutupinya bukan menyebarkannya. Rasulullah Shallallaahu 'alaihi wa sallam mengajarkan kepada kita bahwa siapa yang menutupi aib seseorang di dunia, maka Allah akan menutupi aibnya di dunia dan di akhirat. $^{23}$

Menyebarkan berita aib orang lain sama halnya dengan membicarakan keburukan orang lain. Menyebarkan informasi mengenai aib orang lain adalah dosa

\footnotetext{
22 Muslim. 2006. Shahih Muslim. Riyadh: Dar Thayyibah. No. 4845.

${ }^{23}$ Al Bukhari, Muhammad. 2002. Shahih al Bukhari. Beirut: Dar Ibnu Kastir. No. 2337.
} 
besar yang dilarang di dalam Islam. Dalam menyebarkan berita aib orang lain terdapat maksiat ghibah di dalamnya; maksiat membicarakan kejelekan muslim yang lain yang ia tidak ingin dibicarakan dan dilakukan tanpa sepengetahuannya. Rasulullah Shallallahu 'alaihi wa sallam dalam hadits yang shahih pernah menjelaskan makna ghibah kepada beberapa sahabat. Beliau menyebutkan bahwa ghibah adalah menyebutkan apa yang dibenci oleh saudara muslim tersebut. Salah seorang sahabat bertanya bagaimana jika yang disebutkan itu memang benar adanya. Rasulullah Shallallaahu 'alaihi wa sallam menjawab yang maknanya: "Jika hal tersebut memang benar ada padanya, maka engkau telah mengumpat. Jika hal tersebut tidak ada padanya, maka engkau telah melakukan buhtan (kebohongan)". ${ }^{24}$ Islam juga menganjurkan tidak menyebarkan berita mengenai aib orang lain, bahkan yang diperintahkan adalah menutupi bukan menyebarkan kepada khalayak ramai. Dalam hadits yang shahih Rasulullah Shallallaahu 'alaihi wa sallam menjelaskan bahwa orang yang menutupi aib saudaranya di dunia, maka Allah akan menutupi aibnya di dunia dan di akhirat. ${ }^{25}$

Menyebar berita mengenai kejelekan orang lain bisa saja mendapatkan hudud jika berita itu merupakan penuduhan perzinahan misalnya atau yang dikenal dalam istilah fikih dengan al Qadzf. Menuduh orang lain telah berzina memiliki hukum tersendiri dalam hukum Islam. lafadz-lafadz qadzf pun banyak jumlahnya. Setiap kalimat yang menuduh orang lain berzina, maka dikatakan sebagai qadz. Baik secara jelas seperti fulan pezina maupun secara sindiran dengan niat qadzf seperti fulan fasiq dengan niat fulan adalah pezina, maka yang mengatakan seperti itu dalam hukum Islam wajib dikenakan hudud qadzf. Hudud qadzf sendiri bagi yang merdeka adalah 80 kali cambuk dan 40 kali cambuk bagi hamba sahaya. ${ }^{26}$ Qadzf ini termasuk dosa besar walaupun dalam keadaan bercanda. Dalam satu hadits Rasulullah Shallallaahu 'alaihi wa sallam memerintahkan kepada kita untuk menjauhi 7 perkara yang membinasakan. Di antara tujuh perkara tersebut nabi Shallallaahu 'alaihi wa sallam menyebutkan menuduh zina bagi perempuan-perempuan yang suci yang tidak dikenal dengan keburukan dari mereka. ${ }^{27}$

Pada hakikatnya, Islam melarang menyebarkan berita kejelekan orang lain. Akan

\footnotetext{
24 Muslim. 2006. Shahih Muslim. Riyadh: Dar Thayyibah. No. 4818.

${ }^{25}$ Hanbal, Ahmad. 2009. Musnad Ahmad. Beirut: Muassasah ar-Risalah. No. 16703.

${ }^{26}$ Al Bashir, Waliyuddin. 2010. An-Nihayah. Beirut: Dar al Kutub al 'Ilmiyah. H. 316.

${ }^{27}$ Muslim. 2006. Shahih Muslim. Riyadh: Dar Thayyibah. No. 158.
} 
tetapi, ulama memberikan pengecualian beberapa keadaan untuk menyebarkan berita kejelekan orang lain dengan tujuan yang dibenarkan menurut para ulama. Tujuantujuan yang dibenarkan dari sisi agama untuk menyebarkan berita keburukan orang lain ada enam tujuan.

a) Menghilangkan kezaliman; seperti orang yang terzalimi bisa melaporkan keburukan orang yang menzaliminya kepada pihak yang dapat menghilangkan kezaliman tersebut. Hal ini bisa terlihat di media sosial. Berapa banyak orang yang terzalimi dapat tertolong setelah kezaliman orang tersebut viral di media sosial.

b) Meminta pertolongan untuk menghilangkan kemungkaran; seperti menyampaikan kepada orang yang mampu menghilangkan kemungkaran seseorang yang suka mengkonsumsi narkoba misalnya.

c) Minta fatwa; dibolehkan bagi seseorang menyampaikan kepada seorang mufti: "suamiku menzalimi aku. Apa hukumnya dalam Islam?".

d) Mengingatkan umat Islam dari bahaya seseorang. Misalnya menyampaikan keadaan para periwayat hadits (jarh al majruhin), seseorang meminta pendapat mengenai kejujuran fulan dalam berbisnis, dan pedagang yang suka menipu terlebih lagi di media sosial (jualan online).

e) Pelaku dosa besar secara terang-terangan; seperti seseorang sengaja untuk melakukan dosa besar secara terang-terangan. Orang ini boleh disebutkan keburukannya dengan tujuan agar dia berhenti dari perbuatan dosanya secara terang-terangan.

f) At-Ta'rif; untuk memperkenalkan seseorang yang memang terkenal dengan kekurangannya. Misalnya si buta, si pincang, dan si tuli. Dalam hal ini jika bisa dikenal dengan cara yang lain, maka cara yang lain lebih utama. ${ }^{28}$

3. Tidak menyebarkan berita provokatif

Di antara hal yang perlu diperhatikan saat menyebarkan berita adalah tidak menyebarkan berita yang bersifat provokatif. Hal ini adalah perkara yang dilarang di dalam ajaran Islam dan dikenal dengan sebutan an-Namimah. An-Namimah yang kita kenal dengan istilah Mengadu domba adalah seseorang menyebarkan perkataan dari fulan ke fulan yang lain dengan tujuan terjadi perselisihan dan pertikaian di antara 
mereka. ${ }^{29}$ An-Namimah lebih buruk perbuatannya dibandingkan dengan menyebarkan berita kejelekan orang lain (gosip). Hal ini dikarenakan bahaya dari an-Namimah bisa merusakan tatanan kehidupan masyarakat yang aman dan damai, bahkan bisa memakan nyawa akibat pertikaian yang terjadi. Adapun maksiat gosip tidak sampai pada merusak persatuan dan kesatuan masyarakat.

Menyebarkan berita provokatif termasuk dosa besar dan di antara penyebab seseorang di siksa di kubur jika ia tidak segera bertaubat kepada Allah Subhanahu Wa Ta'ala. Dalam sebuah hadits shahih diceritakan bahwa Rasulullah Shallallahu 'alaihi wa sallam pada suatu hari melewati dua kubur yang sedang disiksa oleh Allah Subhanahu Wa Ta'ala. Penyebab mereka berdua disiksa adalah tidak sempurna melakukan istinja sesudah buang air kecil dan sering mengadu domba ketika semasa hidup di dunia. ${ }^{30}$

Menyebarkan berita provokatif bukanlah termasuk gaya dakwah nabi yang penuh dengan kelembutan dan bahasa yang lebih ramah, sopan, dan merangkul. Berita provokatif tidak dapat memberikan pencerahan, pendidikan, dan perdamaian. Justru berita provokatif dapat menimbulkan kekerasan dan konflik di antara masyarakat. ${ }^{31}$ Padahal Allah Subhanahu Wa Ta'ala sudah mengingatkan untuk berdakwah dengan cara yang penuh dengan kebijaksanaan sebagaimana pada ayat 26 dari surah An-Nahl, bukan dengan cara provokatif dan menyebar kebencian. Berita provokatif kadang menghadirkan berita yang tidak sesuai dengan fakta yang ada di lapangan, sering melakukan dramatisasi serta pengerasan fakta untuk menimbulkan rasa benci dan permusuhan hingga provokasi untuk melakukan tindak kekerasan. Narasumber yang diambil kata-katanya pun berasal dari orang-orang yang paling keras dan paling kontroversial yang bisa memunculkan konflik terbuka dan permusuhan di antara masyarakat. ${ }^{32}$

Islam mengajarkan untuk bagaimana cara menghadapi hoax, berita tentang gosip, dan berita yang provokatif. Di antaranya adalah:

a. Tabayun

Tabayun yang berasal dari akar kata bermakna sesuatu menjadi jelas

\footnotetext{
${ }^{29}$ Al Qar'awiy, Muhammad. 2008. Al Jadid. Jeddah: Maktabah as-Sawadiy. H. 234.

${ }^{30}$ Al Bukhari, Muhammad. 2002. Shahih al Bukhari. Beirut: Dar Ibnu Kastir. No. 1307.

31 Rubawati, Efa. 2018. "Berita Online Sebagai Instrumen Dakwah: Antara Profetik dan Provokatif". TASAMUH: JURNAL STUDI ISLAM, Volume 10, Nomor 1, April 2018. H. 73.

32 Mahfud, Choirul. 2014. Ideologi Media Islam Indonesia Dalam Agenda Dakwah: Antara Jurnalisme Profetik dan Jurnalisme Provokatif. Jurnal Dakwah. Vol. XV, No. 1 Tahun 2014. H. 9.
} 
setelah dikuatkan dengan dalil ${ }^{33}$. Tabayun adalah pengetahuan yang didapat sesudah pencarian yang begitu dalam. Tujuan dari tabayun adalah kehati-hatian dalam menerima informasi dan tidak terburu-buru dalam menerima kebenaran suatu berita serta tidak cepat menyebarkannya tanpa diselidiki dulu tentang kebenarannya. Tabayun sendiri termasuk ciri khas orang yang bijak dalam berpikir dan sebaliknya orang yang tidak suka tabayun merupakan tanda bahwa dirinya tidak bijak dalam berpikir. Tabayun juga termasuk bentuk perlahan-lahan dalam urusan yang mana hal ini adalah sesuatu yang sangat dianjurkan di dalam Islam. Rasulullah Shallallaahu 'alaihi wa sallam pernah bersabda:

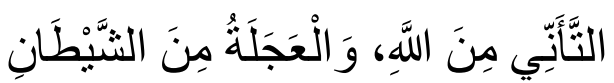

Maknanya: "Perlahan-lahan itu adalah sesuatu yang diridhai oleh Allah dan terburuburu adalah bisikan dari syaithan" (Hadits riwayat al Imam al Baihaqiy No. 20767).

Islam mencela untuk terburu-buru dalam menyebarkan sesuatu tanpa ada klarifikasi terlebih dahulu dan memuji tabayun dalam menerima sebuah informasi. Allah Subhanahu Wa Ta'ala berfirman:

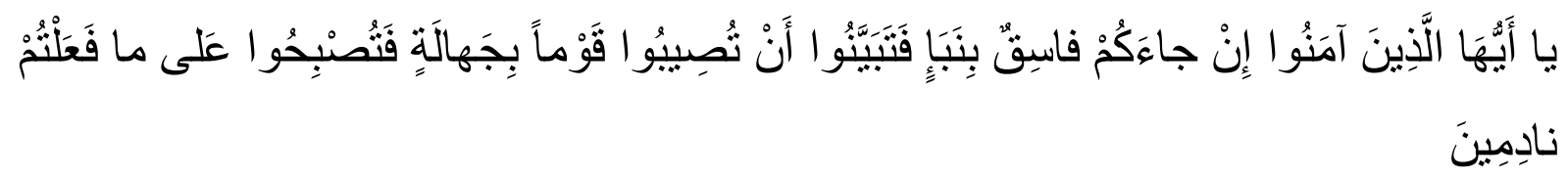

Maknanya: "Hai orang-orang yang beriman, jika datang kepadamu orang fasik membawa suatu berita, maka periksalah dengan teliti agar kamu tidak menimpakan suatu musibah kepada suatu kaum tanpa mengetahui keadaannya yang menyebabkan kamu menyesal atas perbuatanmu itu" (Q.S. al Hujurat: 6). Sebagian orang hanya mendengar berita dari seseorang yang belum jelas kebenaran berita tersebut dan memahami berita tersebut sesuai dengan kecintaan atau kebenciannya terhadap orang yang diberitakan kemudian menyebarkan berita tersebut tanpa klarifikasi berdasarkan kecintaan atau kebenciannya terhadap yang diberitakan. Jika berita yang disebarkan berdasarkan kecintaan kepada yang diberitakan, maka tentunya berita tersebut akan penuh dengan hal-hal yang senang didengar oleh telinga pendengar. Sebaliknya jika berita yang disebarkan berdasarkan kebencian, maka pastinya berita yang disebarkan akan penuh dengan rasa kebencian dan menjatuhkan orang yang diberitakan.

b. Berpikir Positif

\footnotetext{
${ }^{33} \mathrm{Al}$ Jauhari, Ismail. 2008. Mu'jam ash-Shihah. Beirut: Dar al Ma'rifah. H. 120.
} 
Islam mengajarkan untuk selalu berpikir positif saat menerima berita-berita yang mengandung unsur provokasi dan berita hoax. Allah Subhanahu Wa Ta'ala menjelaskan di dalam surah an-Nur ayat 12 bahwa mengapa orang-orang mukmin tidak berprasangka baik terhadap diri mereka sendiri ketika mendengarkan berita bohong. Hal ini menunjukkan bahwa manusia diperintahkan untuk berprasangka baik ketika mendengarkan berita bohong, berita kejelekan orang lain, dan berita yang mengandung provokasi. Di waktu berita hoax tentang Aisyah menyebar, para sahabat bermacammacam keadaannya. Ada yang diam; tidak membenarakan dan tidak pula membantah. Ada yang membicarakannya sambil bertanya-tanya tentang kebenarannya. Ada juga yang dari awal meyakini ketidak benaran berita tersebut dan mempercayai kesucian Sayyidah Aisyah Semoga Allah meridhainya. Ayat ini menganjurkan untuk berpikir positif terhadap diri sendiri; Aisyah yang merupakan istri dari Baginda Rasulullah Shallallaahu 'alaihi wa sallam. Mereka pun dianjurkan untuk mengatakan ini jelas adalah berita kebohongan yang nyata. Hal ini dikarenakan keyakinan mereka terhadao kesucian Aisyah. Oleh karena itu, melalui ayat ini Islam mengajarkan kepada manusia untuk berpikir positif atas berita bohong yang menimpa saudara sendiri, saudara yang seiman, keluarga sendiri, bahkan orang yang sudah dikenal dengan akhlak yang baik.

c. Tidak Menyebar

Langkah selanjutnya yang akan diambil setelah berpikir positif atas berita bohong yang diterima atau berita tentang kejelekan orang lain, maka yang mesti dilakukan adalah tidak menyebar berita tersebut. Hal ini sesuai dengan Firman Allah Subhanahu Wa Ta'ala di dalam Surah al Isra ayat 36 yang mana Allah melarang bagi kita untuk tidak berbicara tanpa ilmu. Karena semua anggota tubuh ini akan diminta pertanggungjawaban di akhirat kelak. Termasuk lidah yang digunakan untuk berbicara kejelekan orang lain, dan jari yang digunakan untuk membagikan berita hoax dan yang berbau provokasi. Ayat 36 dari surah al Isra menganjurkan kepada manusia untuk bijak dalam bermedia sosial sehingga bisa mencegah keburukan yang ada di dalamnya berupa prasangka buruk, berita bohong, dan sebagainya. Ayat itu juga mengingatkan manusia untuk menggunakan telinga dengan baik untuk mendengarkan, menggunakan mata untuk melihat dengan baik, dan menggunakan hati untuk berpikir dengan jernih. Hal ini dikarenakan semua anggota tubuh tersebut akan diminta pertanggungjawaban di akhirat kelak. Seorang muslim harus menahan diri untuk tidak menyebarkan berita 
yang tidak diketahui kebenarannya sampai dia yakin bahwa berita itu bukan berita kebohongan. Kalau pun benar juga, sebaiknya ia tidak menyebarkannya jika tidak ada manfaat dari segi agama dalam menyebarkannya.

\section{Penutup}

\section{Kesimpulan}

Dalam menanggapi suatu berita, seorang muslim mesti lebih teliti mengenai kebenarannya. Walaupun berita tersebut berasal dari orang yang dipercayai, akan tetapi isinya bertolak belakang dengan apa yang kita yakini kebenarannya selama ini berdasarkan al Quran dan hadits yang diajarkan dalam Islam. Dalam hal ini muslim harus lebih teliti dan klarifikasi kepada yang bersangkutan mengenai kebenaran berita tersebut. Karena setiap apa yang ditulis, pada hakikatnya apa yang diucapkan. Setiap yang diucapkan tentunya akan dicatat oleh malaikat di catatan setiap masing-masing muslim.

Ketika menyebarkan berita, seorang muslim juga harus memastikan bahwa berita yang akan disebarkan tidak ada unsur kebohongan (hoax), bukan berita yang membicarakan kejelekan orang lain (ghibah), dan tidak mengandung unsur provokasi sehingga dapat menimbulkan kekacauan dan pertikaian di tengah masyarakat. Dalam menghadapi kecepatan informasi di media sosial, muslim harus selalu mengedepankan prinsip tabayyun (cek terlebih dahulu kebenarannya), selalu berpikir positif atas setiap informasi yang diterima, dan tidak mudah langsung menyebarkan berita yang diterima tanpa melakukan tabayyun terlebih dahulu.

\section{Bibliography}

Afandi, Irfan. Vol. XVI No. 1 April 2018. "Hoax Dalam Sejarah Islam Awal (Kajian Kritis Tentang QS. An-Nur : 11-20)." Ar-Risalah 145-161.

Agung, Pradana. Marisa, Fitri. Vol. 4, No. 1, Januari 2019. "Analisis Statistik Pada Dampak Negatif Dari Sosial Media Terhadap Perilaku Manusia." Journal of Information Technology and Computer Science 1-4.

Al Baihaqiy, Ahmad. 2003. as-Sunan al Kubra. Beirut: Dar al Kutub al 'Ilmiyah.

Al Bashir, Waliyuddin. 2010. an-Nihayah. Beirut: Dar al Kutub al 'Ilmiyah.

Al Bukhariy, Muhammad. 2002. Shahih al Bukhari. Beirut: Dar Ibnu Katsir. 
Al Harari, Abdullah. 2009. 'Umdah ar-Raghib. Beirut: Dar al Masyari'.

Al Jauhari, Ismail. 2008. Mu'jam ash-Shihah. Beirut: Dar Al Ma'rifah.

Al Qar'awiy, Muhammad. 2008. Al Jadid. Jeddah: Maktabah As-Sawadi.

An-Nawawi, Yahya. 1983. Al Adzkar. Beirut: Dar ar Raid al 'Arabiy.

Fathullah. 2007. Komunikasi Etika \& Hubungan Antar Manusia . Semarang: Duta Nusindo.

Hanbal, Ahmad. 2009. Musnad Ahmad. Beirut: Muassas ar-Risalah.

Hibban, Ibnu. 1952. Shahih Ibnu Hibban. Cairo: Dar al Ma'arif.

Ibnu Majah, Muhammad. 2009. Sunan Ibnu Majah. Cairo: Dar Ihya al Kutub al Arabiyah.

Karim, Abdul. 1996. Ithafu Dzawi al Bashair. Riyadh: Dar al 'Ashimah.

KBBI. n.d. Kamus Besar Bahasa Indonesia (Online). Accessed July 15, 2020. https://kbbi.web.id/jurnalistik.

—. n.d. Kamus Besar Bahasa Indonesia. Accessed July 15, 2020. https://kbbi.web.id/fikih.

n.d. Liputan 6. Accessed September 9, 2020. https://www.liputan6.com/news/read/4343268/ternyata-ini-penyulutpembakaran-polsek-ciracas.

Mahfud, Choirul. 2014. "Ideologi Media Islam Indonesia Dalam Agenda Dakwah: Antara Jurnalisme Profetik dan Jurnalisme Provokatif." Jurnal Dakwah Vol. XV, No. 1 Tahun 2014, 1-18.

Maulana, Luthfi. 2017. "Kitab Suci Dan Hoax: Pandangan Alquran Dalam Menyikapi Berita Bohong." Wawasan: Jurnal Ilmiah Agama dan Sosial Budaya 209-222.

Muslim. 2006. Shahih Muslim. Riyadh: Dar Thayyibah.

Rubawati, Efa. 2018. "Berita Online Sebagai Instrumen Dakwah: Antara Profetik dan Provokatif." TASAMUH: JURNAL STUDI ISLAM Volume 10, Nomor 1, April 2018, 65-77.

Tahrun, Houtman, Muhammad Nasir. 2019. Keterampilan Pers Dan Jurnalistik Berwawasan Jender. Yogyakarta: Deepublish. 
